\title{
THE CRIME AGAINST HUMANITY BETWEEN THE STATUTE OF THE HAGUE TRIBUNAL (ICTY) AND SERBIAN CRIMINAL LAW
}

\author{
Dragan Jovašević, Ph.D. \\ University of Niš, Faculty of law, Republic of Serbia
}

International criminal law, as a system of legal regulations found in

acts of the international community and criminal legislations of individual states, establishes criminal liability and punishments for crimes against international law. These acts represent breaches of the laws and customs of war (international humanitarian law) that violate or threaten peace among nations and the security of mankind. Penalties prescribed for these criminal offences stand for the most severe penalties in contemporary criminal legislation. In some cases, international judiciary (supranational) institutions such as The Hague Tribunal (ICTY) and the others of international military and ad hoc tribunals or courts have primary jurisdiction over perpetrators of these criminal offences.

Crime against humanity, defined in paragraph 371. of The New Criminal Code of the Republic of Serbia (2005), represents a newly introduced criminal offence ${ }^{1}$ whose establishment is related to the Statute of The International Military Tribunal from 1945 and the Nurnberg Judgment. It is a serious crime against international law that threatens characteristic values of the entire mankind, or values that are considered as generally humane. The development of the concept of crime against humanity was predominantly influenced by the idea of the need to protect fundamental human rights and freedoms. Crime against humanity (crimen iuris gentium) is based upon violations of fundamental laws of humanity, i.e. each person's right to life and the right of ethnical group to exist as such.

In legislation, theory and practice, this term can be interpreted in the broader sense, as well. In this paper the author has analyzed theoretical and practical aspects of crime against humanity in international criminal law and new criminal law of Republic of Serbia (former FR Yugoslavia).

Key Words: international law, humanity, crime, court, responsibility, penalty

\footnotetext{
${ }^{1}$ Previous absence of this incrimination has been justified by the fact that it has been covered by the crime of genocide, but contemporary practice related to the civil war on the territory of former Yugoslavia indicated that some crimes against the civilian population cannot be treated as genocide since not being aimed to destroy, in whole or in part, a national, racial, religious or ethnical group, whereas the time of their perpetration does not allow them to be considered as war crimes against the civilian population.
} 


\section{The notion and basic characteristics of international crimes}

In the legal system of the Republic of Serbia, crimes against international law are enumerated in the Chapter Thirty Four of The new Criminal Code ${ }^{2}$ from 2005, entitled "Criminal Offences against Humanity and Other Rights Guaranteed by International Law". These criminal offences actually represent acts that constitute violations of international treaties, agreements and conventions and threaten and entrench on peace among nations, the security of mankind and other values protected by the international law or are in breach of the rules of war related to the treatment of war prisoners, wounded, sick and civilians by the parties to the conflict.

The origination of these criminal offences is related to the establishment of international rules organizing relations between states in time of war and relations between the parties to the conflict in view of commencement and conduction of armed conflict. International law of war emerged as the consequence of cruel and inhumane comportment throughout the long history of wars and armed conflicts between nations and states, with the intention to humanize this most inhumane means of resolving international and inter-state disputes. ${ }^{3}$

Along with the expansion of the international law of war, started the process of gradual limitation of the rights belonging to the parties to the conflict, and of controlling not only the acts committed against non-combatants, but those related to the commencement and conduction of war as well. State's right of absolute freedom to commence and conduct a war will gradually be reduced by prohibiting certain acts that include unnecessary devastation, killing and torture. Breaches of the laws and customs of war constitute crimes under the laws of war. Having accepted international obligations by signing and ratifying numerous international conventions, certain states included several criminal offences against humanity and other rights guaranteed by international law in their criminal legislation. Such criminal offences are committed by violating rules contained in international conventions. Their source lays in the prohibitions proclaimed in international legal documents (acts). ${ }^{4}$

Subject of protection under international criminal law consists of humanity and other universally recognized and generally accepted values protected by international law. The protection of humanity pertains to the protection of essential human rights such as: life, physical integrity, honor, reputation and personal dignity and other fundamental human rights and freedoms. Additional rights belonging to natural persons, individual states and the entire international community are also of general, universal significance and therefore protected and guaranteed by international law.

The majority of crimes against the international law can be committed only in a certain period of time determined by the law: ${ }^{5}$

1) During war,

2) Armed conflict or

3) Occupation.

\footnotetext{
${ }^{2}$ Official journal of the Republic of Serbia No.: 85/2005, 88/2005, 107/2005, 72/2009, 111/2009. More: D. Jovašević, Krivični zakonik Republike Srbije sa uvodnim komentarom, Beograd, 2007.

${ }^{3}$ D. Jovašević, Leksikon krivičnog prava, Beograd, 2011. p. 345.

${ }^{4}$ D. Jovašević, Međunarodno krivično pravo, Niš, 2011. pp. 78-86.

${ }^{5}$ V. Đurđić, D. Jovašević, Krivično pravo, Posebni deo, Beograd, 2006. pp. 312-315.
} 


\section{The partition of international crimes}

These criminal offences are most commonly committed in an organized manner with the aim to implement certain governing group's or party's politics. Being considered as an aspect of organized, planned criminality, these offences are most frequently committed by the order of superior military or political leaders. Due to that, it is required to determine individual criminal responsibility of organizer, order-giver and offender.

These criminal offences can be committed only by premeditation. Some of the criminal offences contained in this group are not subject to limitations on criminal prosecution and limitations on enforcement of penalty: genocide, crime against humanity, war crimes and other criminal offences that pursuant to ratified international treaties cannot be subject to limitations.

The theory of international criminal law recognizes several sorts of crimes against international law. They are most commonly divided into two categories ${ }^{6}$ :

1) Crimes against international law in the narrow sense (genuine or pure crimes against international law) and

2) Crimes against international law in the broader sense, or transnational crimes (counterfeit or mixed).

This classification ${ }^{7}$ was adopted for the first time at the 14th Congress of The International Criminal Law Association that took part in Vienna in 1989. The criterion of the division is the jurisdiction of international criminal courts, which is established only in the case of crimes against international law in the narrow sense. Crimes against international law in the narrow sense belong to the first group of these criminal acts. These crimes against international law represent violations of laws and customs of war (meaning the rules of international law of war and international humanitarian law). They are incorporated in the Judgments of the Nurnberg and the Tokyo Tribunal, and are also known as criminal offences under general international law (or crimina iuris gentium). The following criminal offences can be placed in this category ${ }^{8}$ :

1) Crime against peace,

2) War crimes,

3) Genocide and

4) Crime against humanity.

In legal theory, there are opinions suggesting that these criminal offences should be referred to as international crimes stricto sensu that are prohibited by cogent rules of international law such as The Hague or The Geneva Conventions. The following features of crimes against humanity in the broader sense (core crimes) are pointed out in legal theory: ${ }^{9}$

1) These international crimes have double-layered nature. Their commission draws the following consequences: a) individual criminal liability either of a perpetrator or of an accomplice, or of a superior (on the grounds of superior liability) on one hand and b) the responsibility of a state under international law, on the other,

\footnotetext{
${ }^{6}$ B. Petrović, D. Jovašević, Krivično (kazneno) pravo II, Posebni dio, Sarajevo, 2005. pp. 39-41.

${ }^{7}$ Y. Dinstein, M. Tabory, War crimes in International Law, Dordrecht, 1996, pp. 145-167.

${ }^{8}$ O. Triffterer, Acts of violence and international criminal law, Hrvatski ljetopis za kazneno pravo i praksu, Zagreb, No. 2, 1997, pp. 811-824.

${ }^{9}$ D. Radulović, Međunarodno krivično pravo, Podgorica, 1999, pp. 103-105.
} 
2) International crimes violate essential (fundamental) human rights and they are, therefore prohibited as repression against the same crimes committed by the opposite party,

3) International crimes are not subject to limitations on criminal prosecution and limitations on enforcement of penalty and

4) General international law imposes as an erga omnes obligation on the states not to breach the basic rules that prohibit these acts. ${ }^{10}$

\section{The crime against humanity according to The Statute of the Hague Tribunal}

\section{The system of international crimes}

Statute of the International Tribunal for the Prosecution of Persons Responsible for Serious Violations of International Humanitarian Law Committed in the Territory of the Former Yugoslavia since 1991. (ICTY) ${ }^{11}$ was adopted upon Security Council Resolution S/RES/827 from 25 May 1993. The Statute (known as The Hague Statute) recognizes 4 types of crimes against international law. These are: ${ }^{12}$

1) Grave breaches of the Geneva Conventions of 1949,

2) Violations of the laws or customs of war,

3) Genocide and

4) Crimes against humanity.

Imprisonment is the only penalty that can be imposed by the Tribunal, and in determining the terms of imprisonment, the Trial Chambers shall have recourse to the general practice regarding prison sentences in the courts of the former Yugoslavia, taking at the same time into consideration the gravity of the offence (objective circumstances) and the individual characteristics of the convicted person (subjective circumstances) ${ }^{13}$.

In addition to imprisonment, the following sanctions may be also imposed:

1) Return of any property to the rightful owners (restitution) and

2) Confiscation of any proceeds acquired by criminal acts.

\section{Crime against humanity - notion and basic characteristics}

Crime against humanity, also known as the gravest criminal offence of today or the "crime above all crimes", is described in paragraph 5.of The Hague Statute. The practice of the Hague Tribunal has not accepted the extensive interpretation of this crime, which would include the intention to destroy national, linguistic, religious, cultural or any other identity of a group without its physical extermination. ${ }^{14}$

\footnotetext{
${ }^{10}$ D. Jovašević, V. Ikanović, Međunarodno krivično pravo, Banja Luka, 2015, pp. 72-78.

${ }^{11}$ D. Jovašević, Komentar Krivičnog zakona SR Jugoslavije, Beograd, 2002, pp. 14-16.

12 I. Josipović, Pravni i politički aspekta nastanka Međunarodnog kaznenog suda za bivšu Jugoslaviju, Zbornik radova, Hrvatska i Ujedinjeni narodi, Zagreb, 1996, pp. 183-196.

${ }^{13}$ Dž. Džuns, S. Pauls, Međunarodna krivična praksa, Beograd, 2005, pp. 131-147.

${ }^{14}$ D. Jovašević, Međunarodna krivična dela - odgovornost i kažnjivost, Niš, 2010, pp. 231-232.
} 
However, the Hague Statute is familiar with another grave criminal offence whose characteristics and attributes make it similar to the crime of genocide. It is crime against humanity. This criminal offence is found in paragraph 5.of the Hague Statute. The description of this crime against international law clearly states that it can be committed only within an armed conflict (either international or internal in character) and directed only against civilian population, if including: ${ }^{15}$
1) Murder,
2) Extermination,
3) Enslavement,
4) Deportation,
5) Imprisonment,
6) Torture,
7) Rape,
8) Persecutions on political, racial and religious grounds and
9) Committing other inhumane acts.

The abovementioned acts ought to be committed under the following circumstances in order to constitute crime against humanity: ${ }^{16}$

1) An attack has to be committed-an attack can take place even when armed force has not been used, as long as it includes maltreatment of the civilian population or preparations for such acts,

2) Criminal offences committed by the accused have to be a part of that attack,

3) The attack has to be directed against any category of the civilian population,

4) The attack has to be either extensive or systematic. An attack is considered as extensive when being of a wide-spread nature or when being directed against a large number of persons. An attack is described as systematic if the violent acts are committed in an organized manner or with slight probability of being committed accidentally and

5) The perpetrator has to be familiar with (aware of) the fact that his acts are committed within an extensive or systematic attack against civilian population. ${ }^{17}$

Criminal offences against international law, ${ }^{18}$ prescribed by The Statute of The International Criminal Tribunal for Rwanda, and their features and characteristics are the same as those included in the Hague Statute. The Statute of The International Criminal Tribunal for Rwanda was adopted by The UN Security Council Resolution 955 from 8 November 1994. This tribunal has jurisdiction over persons responsible for genocide and other grave violations of international humanitarian law committed in the territory of Rwanda as well as over Rwandan citizens who committed such crimes in the territory of neighboring States during 1994. Since, according to the interpretation of The UN Security Council, there was no armed conflict in this case, this Tribunal has jurisdiction neither for the criminal offence comprised of "grave breaches of the Geneva Conventions of 1949" nor for "violations of the laws or customs of war".

\footnotetext{
${ }^{15}$ M. Simović, M. Blagojević,V. Simović, Međunarodno krivično pravo, Banja Luka, 2013, pp. 27-30.

${ }^{16}$ B. Ivanišević, G. Ilić, T. Višnjić, V. Janjić, Vodič kroz Haški tribunal, Beograd, 2007, pp. 65-67.

${ }^{17}$ P. Novoselec, Opći dio kaznenog prava, Zagreb, 2004, pp. 499-500.

${ }^{18}$ B. Petrović, D. Jovašević, Međunarodno krivično pravo, Sarajevo, 2010, pp. 117-121.

${ }^{19} \mathrm{~S}$. Horović, Genocid, ratni zločini i zločin protiv čovečnosti, Zbornik Pravnog fakulteta u Mostaru, Mostar, 2004, pp. 99-113.
} 
To be exact, the Statute (known as The Statute of The Rwanda Tribunal) is familiar with three types of crimes against international law. These are:

1) Genocide (paragraph 2),

2) Crime against humanity (paragraph 3 ),

3) crime comprised of serious violations of paragraph 3 common to the Geneva Conventions from 1949, and of Additional Protocol II thereto from 1977 (paragraph 4).

\section{The crime against humanity according in the criminal law of the Republic of Serbia} The system of international crimes

Chapter 34. of the Criminal Code of The Republic of Serbia contains the following "genuine" crimes against international law: ${ }^{20}$

1) Genocide (paragraph 373),

2) Crime against humanity (paragraph 371 ),

3) War crime against civilian population (paragraph 372),

4) War crime against the wounded and sick (paragraph 373),

5) War crime against prisoners of war (paragraph 374) and

6) Organizing and Incitement to Genocide and War Crimes (paragraph 375).

The word "genocide" ${ }^{21}$ is a compound, created from a Greek word genos, meaning nation or tribe, and a Latin word caedes, which means killing or slaughter (massacre). When translated literally this word stands for the extermination of an entire nation or tribe. Genocide was proclaimed as "a crime against international law, which is in contradiction with the spirit and the aims of the OUN and condemned by the entire civilized world" by OUN General Assembly Resolution 96/1 from 11 December $1946^{22}$.

In spite of the fact that it initially emerged as a "subspecies of crime against humanity", genocide rapidly obtained autonomous status and contents as one of the most serious crimes of today. Nowadays, it is also called "the crime above all crimes". As a crime against international law, genocide is determined by three elements: ${ }^{23}$

1) The objective component - actus reaus,

2) The subjective component - mens rea and

3) The subject of the act - the victim (the group).

The source of this incrimination is found in Convention on the Prevention and Punishment of the Crime of Genocide from 1948, which defines the contents and the elements of this crime against international law. In legislation, theory and practice this term has a more extensive interpretation. Namely, this expression includes not only killing but also extermination, committed in any other way, of a particular group that forms a consistent entity based upon national, ethnical, racial or religious foundation. The subject of protection includes humanity and international law.

\footnotetext{
${ }^{20}$ D. Jovašević, Krivično pravo, Posebni deo, Beograd, 2014, pp. 322-341.

${ }^{21}$ D. Jovašević, Međunarodno krivično pravo, Niš, 2011, pp. 80-92.

${ }^{22}$ Official Gazette of the SFR Yugoslavia No. 56/1950.

${ }^{23}$ Lj. Lazarević, B. Vučković, V. Vučković, Komentar Krivičnog zakonika Crne Gore, Cetinje, 2004, pp. 1021-1023.
} 


\section{Crime against humanity - notion and basic characteristics}

Crime against humanity ${ }^{24}$, defined in paragraph 371. of The New Criminal Code of the Republic of Serbia (2005), ${ }^{25}$ represents a newly introduced criminal offence ${ }^{26}$ whose establishment is related to the Statute of The International Military Tribunal from 1945 and the Nurnberg Judgment. ${ }^{27}$ It is a serious crime against international law that threatens characteristic values of the entire mankind, or values that are considered as generally humane. The development of the concept of crime against humanity was predominantly influenced by the idea of the need to protect fundamental human rights and freedoms.

Crime against humanity ${ }^{28}$ (crimen iuris gentium) is based upon violations of fundamental laws of humanity, i.e. each person's right to life and the right of each ethnical group to exist as such.

Accordingly, the acts in question are directed against the conditions that are essential for the survival of a human being, individual human groups and mankind as a whole. Therefore, legal theory points out the following elements of crimes against humanity: ${ }^{29}$

1) The latter are considered as particularly abhorrent violations that seriously offend human dignity and cause humiliation of one or several persons

2) These crimes are not isolated or sporadic cases, but are committed as a part of certain state government's politics or as an extensive or systematic practice, which is tolerated, pardoned or accepted, either by the official government or by the unofficial (de facto) regime,

3) The acts in question are prohibited and punishable whether committed in war or in peace,

4) The victims of this crime can be the civilians, or, if committed during an armed conflict, persons who do not participate or who no longer participate in the conflict, as well as the combatants of the opposite party, in accordance with the international customary law.

${ }^{24}$ D. Jovašević, Krivično pravo, Posebni deo, Beograd, 2014, pp. 324-325.

${ }^{25}$ Official Gazette of the Republic of Serbia No. 85/2005, 88/2005, 115/2005, 72/2009 and 111/2009. More: D. Jovašević, Krivični zakonik Republike Srbije sa uvodnim komentarom, Beograd, 2007.

${ }^{26}$ Previous absence of this incrimination has been justified by the fact that it has been covered by the crime of genocide, but contemporary practice related to the civil war on the territory of former Yugoslavia indicated that some crimes against the civilian population cannot be treated as genocide since not being aimed to destroy, in whole or in part, a national, racial, religious or ethnical group, whereas the time of their perpetration does not allow them to be considered as war crimes against the civilian population.

${ }^{27}$ It is assumed that one of the first judgments dealing with crime against humanity is the judgment of The Special Court of Cassation of Holland from 1949, saying that the characteristics of the crimes of this category include gravity and ferociousness, large extensions, the fact that they represent a part of the system aimed to spread terror or a link in politics deliberately conducted against some groups of population

${ }^{28}$ Z. Pajić, Zločin protiv čovečnosti - problem međunarodne odgovornosti, Jugoslovenska revija za međunarodno pravo, Beograd, No. 2-3, 1986, pp. 304-316.

${ }^{29}$ B. Petrović, D.Jovašević, Krivično (kazneno) pravo II, Posebni dio, Sarajevo, 2005, pp. 42-44. 
This criminal offence is committed if a person, in violation of the rules of international law, as part of a wider ${ }^{30}$ and systematic ${ }^{31}$ attack against civilian population ${ }^{32}$ orders or commits: murder, inflicting on the group conditions of life calculated to bring about its complete or partial extermination, ${ }^{33}$ enslavement, deportation, torture, rape, forcing to prostitution, forcing pregnancy or sterilization aimed at changing the ethnic balance of the population, persecution ${ }^{34}$ on political, racial, national, ethical, sexual or other grounds, detention or abduction of persons without disclosing information on such acts in order to deny such person legal protection, oppression of a racial group or establishing domination or one group over another, or other similar inhumane acts that intentionally cause serious suffering or serious endangering of human health.

The subjects of protection are humanity and international law.

The subject of the attack is the civilian population, i.e. members of the entire noncombating population regardless of their citizenship, who found themselves on the occupied territory or territory under the regime of the opposite party.

Although this criminal offence is committed by conducting certain acts against individuals, its aim is not to eliminate those individuals as particular persons but to contribute to the conduction of a wider or systematic attack directed against the entire civilian population. Accordingly, the intent is to destroy (exterminate) the entire or the majority of the civilian population, whereas the elimination of individuals represents only a means of accomplishing this intent. Namely, it refers to acts repeatedly committed against civilians on grounds of or with the intent to realize particular state's politics or the politics of a certain organization (e.g. a political party or similar organization). The aim of this incrimination is to ensure every person's right to life along with providing respect of fundamental human rights and freedoms. ${ }^{35}$

\section{The actions to exhibit of this crime}

The criminal act is comprised of a series of diverse acts that can be divided into several categories: ${ }^{36}$

1. Killing another person-murder,

${ }^{30}$ The term "wider attack" should be interpreted as the fact that the armed conflict is taking place on a broader territory.

${ }^{31}$ The term "systematic attack" should be interpreted as a planned attack, on which an arrangement has previously been achieved and certain directions given. The plan can be incorporated in a broader military or political plan, but can also be related to particular operations.

${ }^{32}$ The attack directed against the civilian population signifies the behavior that includes repeated perpetration of the acts enumerated in the law against any civilian population, on the grounds or with the aim of certain state's politics or the politics of an organization to commit such attack.

${ }^{33}$ Extermination includes deliberately imposing such conditions, especially deprivation of access to food and medicaments, which can cause the destruction of a part of the population.

${ }^{34}$ The persecution can be related to any group of people or community on political, racial, national, ethnical, cultural, religious, sexual, or other grounds, which is universally recognized as unacceptable in international law with regard to any criminal act. This situation includes deliberate and severe deprivation, or denial of fundamental human rights and freedoms due to the membership in a particular group of people or community, which is in contradiction with international law.

${ }^{35}$ M. Simović, M. Blagojević, V. Simović, Međunarodno krivično pravo, Banja Luka, 2013, pp. 130-135.

${ }^{36}$ B. Petrović, D. Jovašević, A. Ferhatović, Krivično parvo 1, Sarajevo, 2015, pp. 163-168. 
2. Inflicting on the population or its part conditions of life calculated to bring about its complete or partial extermination, ${ }^{37}$

3. Enslavement or compulsory deportation of the population

4. Torture,

5. Raping, forcing to prostitution, forcing pregnancy or sterilization aimed at changing the ethnic balance of the population

6. Persecution ${ }^{38}$ grounded on political, racial, national, ethical, cultural, sexual or other grounds,

7. Detention or abduction of persons without disclosing information on such acts in order to deny such person legal protection,

8. Oppression of a racial group or establishing domination or one group over another,

9. Other similar inhumane acts that intentionally cause serious suffering or seriously endanger human health

The criminal act can be perpetrated in two ways:

1) By ordering and

2) By directly committing the act.

Giving order to commit the previously mentioned acts represents a particular and an autonomous act of crime against humanity.

In general, ordering represents a form of incitement. However, in this case it is not treated as complicity, but as a special way to commit this criminal offence. This criminal offence is usually committed in an organized and systematic manner in accordance with a previously designed plan, giving a special power to the order of a superior, which causes the autonomous nature of its criminal responsibility. To be exact, the superior will be responsible for having ordered crime against humanity to be committed even if the subordinate refused or in any other way avoided to obey such order.

It is essential for the criminal act that one or more acts are committed repeatedly: ${ }^{39}$

1) By violating rules of international law and therefore unlawfully, which the perpetrator has to be aware of and lation.

2) As part of a wider and systematic attack directed against any part of civilian popu-

According to the grammatical interpretation of this paragraph, one might conclude that this criminal offence can be committed only during an armed conflict („within the attack"), which is incorrect. It is more appropriate to assume that crimes of this kind can be committed during as well as after the armed conflict, as long as the criminal acts are being perpetrated in the context of wider or systematic attack directed against the civilian population. ${ }^{40}$

\footnotetext{
${ }^{37}$ Extermination includes deliberately imposing such conditions, especially deprivation of access to food and medicaments, which can cause the destruction of a part of the population.

${ }^{38}$ The persecution can be related to any group of people or community on political, racial, national, ethnical, cultural, religious, sexual, or other grounds, which is universally recognized as unacceptable in international law with regard to any criminal act. This situation includes deliberate and severe deprivation, or denial of fundamental human rights and freedoms due to the membership in a particular group of people or community, which is in contradiction with international law.

${ }^{39}$ D. Radulović, Međunarodno krivično pravo, Podgorica, 1999, pp. 115-120.

${ }^{40}$ Z. Pajić, Međunarodna odgovornost za zločin protiv čovečnosti u svjetlu nirnberških načela i savremenih shvatanja, Godišnjak Pravnog fakulteta u Sarajevu, Sarajevo, 1986, pp. 109-134.
} 
The consequence of the act emerges as an injury or as the deprivation of fundamental human rights and freedoms of the civilian population. It can be completed by causing a smaller or a larger amount of individual consequences. The number of individual consequences does not influence the existence of the criminal offence, but has an impact on the determination of punishment. ${ }^{41}$

Any person can be the perpetrator of this criminal offence, and, when guilt is concerned, direct premeditation is required.

The punishment prescribed for this criminal act is minimum five years' prison or thirty to forty years' prison.

The New Criminal Code of the Republic of Serbia from 2005. explicitly points out that this criminal offence is not subject to limitations on criminal prosecution and limitations on enforcement of penalty.

\section{Conclusion}

International criminal law, as a system of legal regulations found in acts of the international community and criminal legislations of individual states, establishes criminal liability and punishments for crimes against international law. These acts represent breaches of the laws and customs of war (international humanitarian law) that violate or threaten peace among nations and the security of mankind. Penalties prescribed for these criminal offences stand for the most severe penalties in contemporary criminal legislation.

In some cases, international judiciary (supranational) institutions such as The Nurnberg and The Tokyo Tribunal, The Hague Tribunal, The Rome Court etc. have primary jurisdiction over perpetrators of these criminal offences. Due to its significance, nature and character, the crime above all crimes stands out among all the crimes against international law. It is the crime against humanity.

Crime against humanity (crimen iuris gentium) is based upon violations of fundamental laws of humanity, i.e. each person's right to life and the right of each ethnical group to exist as such. Accordingly, the acts in question are directed against the conditions that are essential for the survival of a human being, individual human groups and mankind as a whole.

Therefore, legal theory points out the following elements of crimes against humanity : 1) the latter are considered as particularly abhorrent violations that seriously offend human dignity and cause humiliation of one or several persons, 2) these crimes are not isolated or sporadic cases, but are committed as a part of certain state government's politics or as an extensive or systematic practice, which is tolerated, pardoned or accepted, either by the official government or by the unofficial (de facto) regime, 3) the acts in question are prohibited and punishable whether committed in war or in peace and 4) the victims of this crime can be the civilians, or, if committed during an armed conflict, persons who do not participate or who no longer participate in the conflict, as well as the combatants of the opposite party, in accordance with the international customary law.

This criminal offence (inclusion international criminal law and criminal law of the Republic of Serbia) is committed if a person, in violation of the rules of international law, as part of a wider and systematic attack against civilian population orders or commits: murder, inflicting on the group conditions of life calculated to bring about its complete or partial extermination, enslave-

\footnotetext{
${ }^{41}$ B. Pavišić, V. Grozdanić, P. Veić, Komentar Kaznenog zakona, Zagreb, 2007, pp. 428-431.
} 
ment, deportation, torture, rape, forcing to prostitution, forcing pregnancy or sterilization aimed at changing the ethnic balance of the population, persecution on political, racial, national, ethical, sexual or other grounds, detention or abduction of persons without disclosing information on such acts in order to deny such person legal protection, oppression of a racial group or establishing domination or one group over another, or other similar inhumane acts that intentionally cause serious suffering or serious endangering of human health.

\section{Literature}

[1] Official journal of the Republic of Serbia No.: 85/2005, 88/2005, 115/2005, 107/2005, 72/2009, 111/2009.

[2] Official Gazette of the SFR Yougoslavia, No. 56/1950.

[3] D. Jovašević, Krivični zakonik Republike Srbije sa uvodnim komentarom, Beograd, 2007.

[4] D. Jovašević, Leksikon krivičnog prava, Beograd, 2011.

[5] D. Jovašević, Međunarodno krivično pravo, Niš, 2011.

[6] V. Đurđić, D. Jovašević, Krivično pravo, Posebni deo, Beograd, 2006.

[7] B. Petrović, D. Jovašević, Krivično (kazneno) pravo II, Posebni dio, Sarajevo, 2005.

[8] Y. Dinstein, M. Tabory, War crimes in International Law, Dordrecht, 1996.

[9] O. Triffterer, Acts of violence and international criminal law, Hrvatski ljetopis za kazneno pravo i praksu, Zagreb, No. 2, 1997.

[10] D. Radulović, Međunarodno krivično pravo, Podgorica, 1999.

[11] D. Jovašević, V. Ikanović, Međunarodno krivično pravo, Banja Luka, 2015.

[12] D. Jovašević, Komentar Krivičnog zakona SR Jugoslavije, Beograd, 2002.

[13] I. Josipović, Pravni i politički aspekta nastanka Međunarodnog kaznenog suda za bivšu Jugoslaviju, Zbornik radova, Hrvatska i Ujedinjeni narodi, Zagreb, 1996.

[14] Dž. Džuns, S. Pauls, Međunarodna krivična praksa, Beograd, 2005.

[15] D. Jovašević, Međunarodna krivična dela - odgovornost i kažnjivost, Niš, 2010.

[16] M. Simović, M. Blagojević,V. Simović, Međunarodno krivično pravo, Banja Luka, 2013.

[17] B. Ivanišević, G. llić, T. Višnjić, V. Janjić, Vodič kroz Haški tribunal, Beograd, 2007.

[18] P. Novoselec, Opći dio kaznenog prava, Zagreb, 2004.

[19] B. Petrović, D. Jovašević, Međunarodno krivično pravo, Sarajevo, 2010.

[20] S. Horović, Genocid, ratni zločini i zločin protiv čovečnosti, Zbornik Pravnog fakulteta u Mostaru, Mostar, 2004.

[21] D. Jovašević, Krivično pravo, Posebni deo, Beograd, 2014.

[22] Lj. Lazarević, B. Vučković, V. Vučković, Komentar Krivičnog zakonika Crne Gore, Cetinje, 2004.

[23] D. Jovašević, Krivično pravo, Posebni deo, Beograd, 2014.

[24] Z. Pajić, Zločin protiv čovečnosti - problem međunarodne odgovornosti, Jugoslovenska revija za međunarodno pravo, Beograd, No. 2-3, 1986.

[25] B. Petrović, D. Jovašević, A. Ferhatović, Krivično parvo 1, Sarajevo, 2015.

[26] D. Radulović, Međunarodno krivično pravo, Podgorica, 1999, pp. 115-120.

[27] Z. Pajić, Međunarodna odgovornost za zločin protiv čovečnosti u svjetlu nirnberških načela i savremenih shvatanja, Godišnjak Pravnog fakulteta u Sarajevu, Sarajevo, 1986.

[29] B. Pavišić, V. Grozdanić, P. Veić, Komentar Kaznenog zakona, Zagreb, 2007. 